\title{
Mechanism of action of a new antitumor ribonucleoside, 1-(3-C-ethynyl-ß3-D-ribo-pentofuranosyl)cytosine (ECyd, TAS-106), differs from that of 5-fluorouracil
}

\author{
HIROMI KAZUNO ${ }^{1}$, YUJI SHIMAMOTO ${ }^{2}$, HIROAKI TSUJIMOTO ${ }^{3}$, \\ MASAKAZU FUKUSHIMA ${ }^{3}$, AKIRA MATSUDA ${ }^{4}$ and TAKUMA SASAKI ${ }^{5}$
}

\begin{abstract}
${ }^{1}$ Hanno Research Center, Taiho Pharmaceutical Co., Ltd., 1-27 Misugidai, Hanno-city, Saitama 357-8527;
${ }^{2}$ Taiho Pharmaceutical Co., Ltd., 2-9-12 Kaji-cho, Chiyoda-ku, Tokyo 101-0044; ${ }^{3}$ Tokushima Research Center, Taiho Pharmaceutical Co., Ltd., 224-2 Hiraishi-Ebisuno, Kawauchi, Tokushima 771-0194; ${ }^{4}$ Graduate School of Pharmaceutical Sciences, Hokkaido University, Kita-12 Nishi-6, Kita-ku, Sapporo 060-0812;

${ }^{5}$ Aichi-Gakuin University, 1-100 Kusumoto-cho, Chikusa-ku, Nagoya 464-8650, Japan
\end{abstract}

Received January 23, 2007; Accepted February 26, 2007

\begin{abstract}
C-ethynyl-3-D-ribo-pentofuranosyl)cytosine (ECyd, TAS-106), is a new antitumor cytidine analogue, inhibiting RNA synthesis. In this study we investigated the cellular growth inhibition, intracellular metabolism, cell cycle phase specificity, and RNA synthesis of TAS-106 compared with those of 5-fluorouracil (5-FU), known to possess both DNA- (inhibition of thymidylate synthase activity) and RNAsynthesis-inhibiting activity (inhibition of RNA function). The $\mathrm{IC}_{50}$ values of TAS-106 and 5-FU ranged from 0.0173 to $3.11 \mu \mathrm{M}$, and from 6.80 to $>1,000 \mu \mathrm{M}$, respectively, in a panel of 10 human tumor cells, indicating that TAS-106 possesses greater cytotoxicity than 5-FU. Using excess thymidinesynchronized cells, TAS-106 and 5-FU appeared to exert their cytotoxic effects independently of the cell cycle. The intracellular metabolism and the effect on pre-rRNA processing of TAS-106 differed from those of 5-FU. More than 50\% of 5-FU incorporated into the cells was in the unchanged form, while 5-FU incorporated into RNA was approximately $20 \%$. On the other hand, TAS-106 was incorporated in a timedependent manner into the cells and rapidly converted to its mono-, di- and tri-phosphate form, however, the amount incorporated into RNA fraction was very small. 5-FU incorporated into RNA was confirmed to impair the normal processing of ribosomal RNA (formation of 34/32S RNA from 45S RNA), however, TAS-106 did not affect pre-rRNA processing and may be involved in the inhibition of the
\end{abstract}

Correspondence to: Dr Hiromi Kazuno, Hanno Research Center, Taiho Pharmaceutical Co., Ltd., 1-27 Misugidai, Hanno-city, Saitama 357-8527, Japan

E-mail: h-kazuno@taiho.co.jp

Key words: 1-(3-C-ethynyl-ß-D-ribo-pentofuranosyl)cytosine, ECyd, TAS-106, 5-fluorouracil, intracellular metabolism, RNA processing, cell cycle phase specificity synthesis of ribosomal RNA. We concluded that intracellular accumulation and retention of the active metabolite of TAS106, 3'-ethynylcytidine 5'-triphosphate (ECTP), may contribute to its potent cytotoxicity. The unique mechanism of antitumor activity and intensive cellular metabolism of TAS-106 could contribute to cancer chemotherapy through the pathways different from those of 5-FU or other antitumor nucleosides.

\section{Introduction}

1-(3-C-ethynyl-B-D-ribo-pentofuranosyl)cytosine (3'-ethynylcytidine, ECyd, TAS-106) is a new antitumor cytidine analogue possessing a potent cytotoxic and antitumor activity in preclinical therapeutic models, which recently underwent a phase I clinical study in the United States (1-4). The preliminary studies revealed that cytotoxic effects of TAS-106 are mainly related to the interference with RNA metabolism $(5,6)$. TAS106 is converted into the 3'-ethynylcytidine-5'-monophosphate (ECMP) by uridine-cytidine kinase (UCK; EC 2.7.1.48) (7), and this product is subsequently phosphorylated to the $3^{\prime}$ ethynylcytidine-5'-diphosphate (ECDP) and then to the 3'ethynylcytidine-5'-triphosphate (ECTP).

Moreover, the preliminary experiments also revealed a competitive inhibition of RNA polymerase by ECTP with a $\mathrm{Ki}$ value of $21 \mathrm{nM}$ when assayed in the presence of isolated nuclei from FM3A mouse tumor cells (the Km value of CTP was $8.0 \mu \mathrm{M}$.). ECTP was found to be the major intracellular metabolite accumulating in the cells exposed to TAS-106 for $4 \mathrm{~h}$, and then was very slowly eliminated from the cells.

5-Fluorouracil (5-FU) has been widely used for the treatment of patients with gastric, colorectal, lung, head and neck and breast cancer. The cytotoxicity of 5-FU is exerted by its two active metabolites, namely, 5-fluoro-2'-deoxyuridine-5'monophosphate (FdUMP) and 5-fluorouridine-5'-triphosphate (FUTP). FdUMP forms a covalent ternary complex with thymidylate synthase (TS; EC 2.1.1.45) and 5,10- $\mathrm{CH}_{2}-\mathrm{FH}_{4}$, which inhibits the conversion of 2'-deoxyuridine-5'-monophosphate (dUMP) to 2'-deoxythymidylate and results in the 
decreased DNA synthesis (8-11). Another metabolic pathway of 5-FU involving FUTP, leads to its incorporation into RNA instead of uridine-5'-triphosphate, resulting in interference with the maturation of RNA and finally in improper functioning of RNA (12-15).

The purpose of this study was to clarify the differences between TAS-106 and 5-FU in their mechanisms of interference with RNA synthesis, which may be essential for the fitting of the different profile of anticancer activity to cancer types expressing particular pathways. This may result in more precise stratification of cancer patients to the most optimal treatment modality.

\section{Materials and methods}

Chemicals. TAS-106 and $a, a, a$,-trifluorothymidine (FTD) were synthesized at Taiho Pharmaceutical Co., Ltd. (Tokyo, Japan). 5-FU was obtained from Wako Pure Chemical Industries, Ltd. (Osaka, Japan). All other chemicals were commercial products of the highest quality available.

Cells and cell culture. HT-1080, human fibrosarcoma cells were generously supplied by Dr Takuma Sasaki (Cancer Research Institute, Kanazawa University). KB human nasopharyngeal carcinoma cells were purchased from the American Type Culture Collection (Rockville, MD). HCT-15 human colon carcinoma cells, A549 human lung carcinoma cells, BxPC-3 human pancreas carcinoma cells, and PC-3 human prostate cells were purchased from Dai-Nippon Pharmaceutical Co., Ltd. (Osaka, Japan). AZ521 human gastric carcinoma cells and T.T human esophagus carcinoma cells were purchased from the Japanese Cancer Research Resources Bank (Tokyo, Japan). VMRC-RCW human renal carcinoma cells, ME-180 human cervix carcinoma cells, and T24 human bladder carcinoma cells were purchased from the Health Science Research Resources Bank (Osaka, Japan). Li-4 human liver carcinoma cells, maintained as an in vivo growing tumor, were obtained from the Central Institute for Experimental Animals (Tokyo, Japan).

HT-1080 cells, HCT-15 cells, BxPC-3 cells and PC-3 cells were maintained in RPMI-1640 medium supplemented with $10 \%$ heat-inactivated fetal bovine serum (FBS; ICN Biomedicals, Inc., Aurora, OH). KB cells were maintained in Eagle's minimum essential medium (MEM) containing $1 \mathrm{x}$ nonessential amino acids (NEAA) and 10\% (v/v) FBS. VMRCRCW cells, ME-180 cells and T24 cells were maintained in MEM containing 10\% (v/v) FBS. A549 cells and AZ521 cells were maintained in Dulbecco's modified MEM (DMEM) containing $10 \%$ (v/v) FBS. T.T cells were maintained in DMEM/ Ham's F-12 medium (1:1) supplemented with 10\% FBS. Li-4 cells were maintained with MEM containing $2 \mathrm{x}$ vitamin, $0.1 \mathrm{M}$ sodium pyruvate, $1 \times$ NEAA, and $10 \%$ (v/v) FBS. The cells were incubated at $37^{\circ} \mathrm{C}$ in a humidified atmosphere containing $5 \% \mathrm{CO}_{2}$.

Chemosensitivity test. The growth inhibitory effects of the drugs on human cancer cells were determined by colorimetric tetrazolium-formazan (MTT) assay (16). Briefly, 180- $\mu 1$ aliquots of an exponentially growing cell suspension $\left(1-5 \times 10^{3}\right.$ cells/180 $\mu \mathrm{l} /$ well) were incubated in 96-well microplates for $24 \mathrm{~h}$. A $20-\mu \mathrm{l}$ volume of various concentrations of the drugs was then added. After exposure to the drugs for $72 \mathrm{~h}, 25 \mu 1$ of $2 \mathrm{mg} / \mathrm{ml}$ MTT reagent (Sigma Chemical Co., St. Louis, MO) was added to each well, and the cells were incubated at $37^{\circ} \mathrm{C}$ for $4 \mathrm{~h}$. The culture medium in all of the wells was removed, and the cells were dissolved in DMSO $(150 \mu 1)$. After thorough mixing, the absorbance of each well was measured at $540 \mathrm{~nm}$ with a Model 3550 microplate reader (Bio-Rad Laboratories, Hercules, CA). The $\mathrm{IC}_{50}$ was defined as the drug concentration needed to produce a $50 \%$ reduction of growth relative to the control.

Measurement of intracellular metabolism. The SchmidtThannhauser-Schneider method was used to determine the incorporation into the nucleic acid fractions (17).

HT-1080 human fibrosarcoma cells $\left(1.7 \times 10^{7}\right.$ cells $)$ were exposed for $0.5,1$ or $2 \mathrm{~h}$ in a total volume of $1 \mathrm{ml}$ RPMI-1640 medium supplemented with $1 \% \mathrm{FBS}$ and $1 \mu \mathrm{M}, 1 \mu \mathrm{Ci}$ of $\left[{ }^{3} \mathrm{H}\right] \mathrm{TAS}-106$ or $\left[{ }^{3} \mathrm{H}\right] 5-\mathrm{FU}$. After the termination of the reaction, the cells were collected by centrifugation $(150 \mathrm{x} \mathrm{g}$, $4^{\circ} \mathrm{C}, 5 \mathrm{~min}$ ) and washed twice with $2 \mathrm{ml}$ of ice-cold PBS (Nissui Pharmaceutical Co., Ltd., Tokyo, Japan). The acidsoluble fraction was prepared by adding $2 \mathrm{ml}$ of ice-cold $5 \%$ trichloroacetic acid (TCA) to the cell pellet, roughly mixing, and placing on ice for $10 \mathrm{~min}$. The acid-soluble fraction and the acid-insoluble fraction were then separated by centrifugation (500 x g, $4^{\circ} \mathrm{C}, 5 \mathrm{~min}$ ). Two $\mathrm{ml}$ aliquot of the supernatant was added with $2 \mathrm{ml}$ of a mixture of $17.7 \%$ (v/v) tri-n-octylamine/ 1,1,2-trichloro-1,2,2-trifluoroethane and roughly vortexed. The particulate material was separated by centrifugation (1,200 x g, room temperature, $5 \mathrm{~min})$, and the resulting aqueous layer (1.5 $\mathrm{ml}$ of top layer) was separated and evaporated to dryness. The died residue was dissolved in $100 \mu \mathrm{l}$ of distilled water and a $20-\mu 1$ aliquot of this concentrated acid-soluble fraction was spotted on a silica gel $60 \mathrm{~F}_{254}$ thin-layer chromatography (TLC) plate $(2.5 \times 10 \mathrm{~cm}$, Merck). In the case of [ $\left.{ }^{3} \mathrm{H}\right] \mathrm{TAS}-106$ experiments, the plates were developed with a mixture of chloroform/methanol/acetic acid (14/6/1, v/v/v). The ethynylnucleotides generated from TAS-106 remained at the origin while the intact TAS-106 moved upward and was easily separated. A similar approach was used in the case of $\left[{ }^{3} \mathrm{H}\right] 5-\mathrm{FU}$, however, the mobile phase consisted of a mixture of chloroform/methanol/acetic acid (17/3/1, v/v/v). Under these conditions the 5-FU-derived nucleotides remained at the origin, while 5-FU, 5-fluoro-2'-deoxyuridine (FdUrd) and 5-fluorouridine (FUrd) were well separated and measured. To analyze the nucleotide fractions, the other $20 \mu 1$ of the concentrated acid-soluble fraction was spotted on a polyethyleneimine (PEI)cellulose F TLC plate (3x10 cm, Merck), and developed up to $1 \mathrm{~cm}$ with distilled water, and then subsequently developed with a mixture of $1 \mathrm{M}$ acetic acid/1 $\mathrm{M}$ lithium chloride (1/1, $\mathrm{v} / \mathrm{v})$. This approach allowed the separation of the phosphorylated species generated both from TAS-106 and 5-FU. The individual fractions separated by TLC were scraped off and placed in the vials, and $0.5 \mathrm{ml}$ of $1 \mathrm{~N} \mathrm{HCl}$ and $10 \mathrm{ml}$ of ACS-II scintillator (Amersham, Buckinghamshire, UK) were added, and the radio-activity was measured with an LSC-5101 liquid scintillation counter (Aloka Co., Ltd., Tokyo, Japan).

Incorporation of TAS-106 and 5-FU into DNA and RNA. Subsequently, $2 \mathrm{ml}$ of ice-cold 5\% TCA was again added to the 

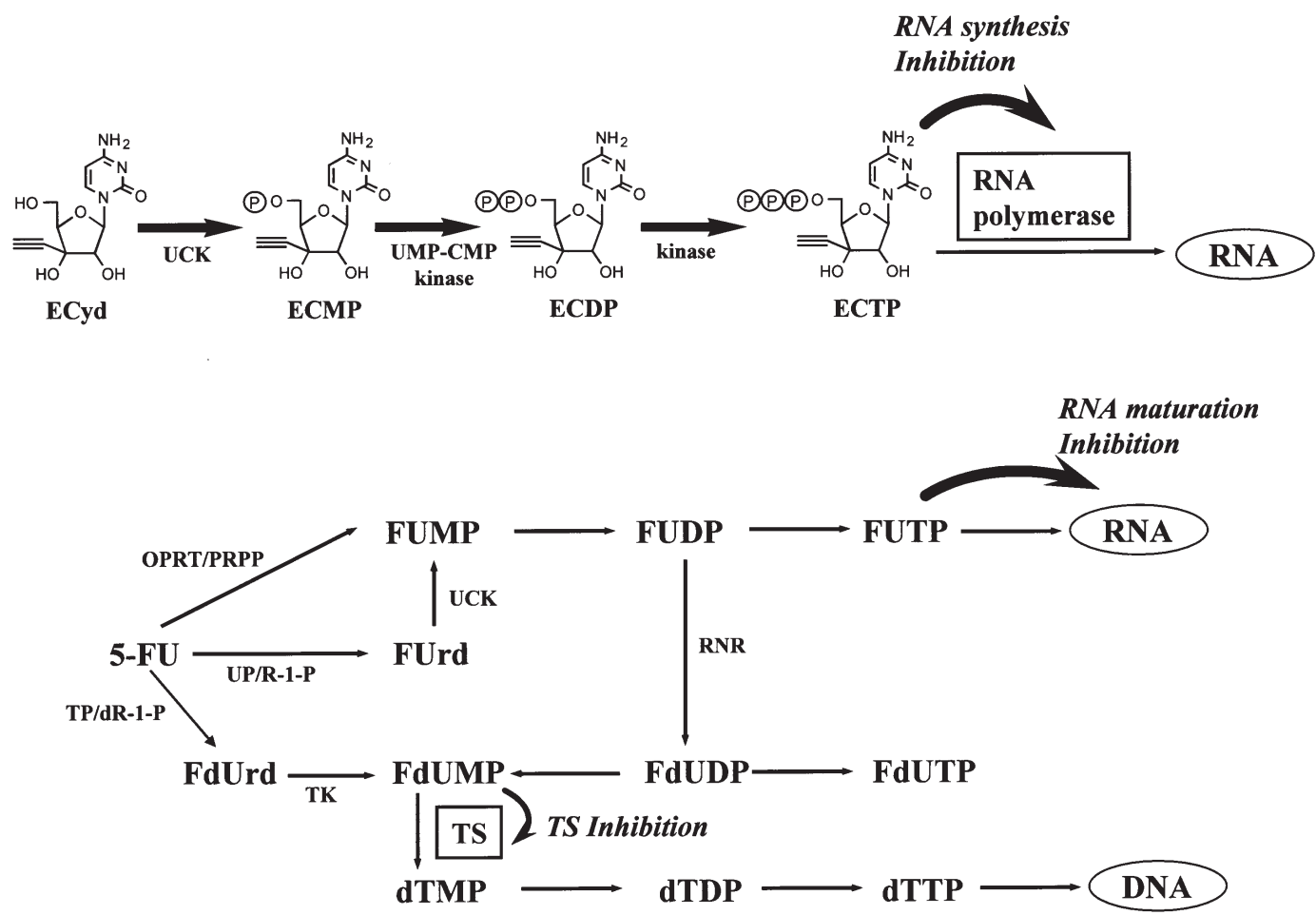

Figure 1. Metabolic activation pathways and antitumor mechanism of TAS-106 (ECyd) and 5-FU. Enzyme/cosubstrate: UCK, uridine-cytidine kinase; UMPCMP kinase, uridine-cytidine monophosphate kinase; OPRT/PRPP, orotate phosphoribosyltransferase/5-phosphoribosyl-1-pyrophosphate; UP/R-1-P, uridine phosphorylase/ribose-1-phosphate; TP/dR-1-P, thymidine phosphorylase/deoxyribose-1-phosphate; TK, thymidine kinase; TS, thymidylate synthase; RNR, ribonucleotide reductase.

acid-insoluble fraction containing RNA and DNA, and the resulting precipitate was washed and separated by centrifugation $\left(500 \mathrm{x} \mathrm{g}, 4^{\circ} \mathrm{C}, 5 \mathrm{~min}\right)$. The pellet was suspended in $1 \mathrm{ml}$ of distilled water and, after adding $4 \mathrm{ml}$ of ethanol, allowed to stand on ice for $5 \mathrm{~min}$, and then centrifuged $(1,200 \mathrm{x} \mathrm{g}$, $\left.4^{\circ} \mathrm{C}, 5 \mathrm{~min}\right)$. The obtained pellet was suspended in $4 \mathrm{ml}$ of a mixture of ethanol/diethyl ether $(1 / 1, \mathrm{v} / \mathrm{v})$, and heated at $37^{\circ} \mathrm{C}$ for $10 \mathrm{~min}$, then centrifuged $(1,200 \mathrm{x} \mathrm{g}$, room temperature, $5 \mathrm{~min})$. A $2-\mathrm{ml}$ volume of $0.3 \mathrm{~N} \mathrm{KOH}$ was added to this pellet to hydrolyze RNA by incubating at $37^{\circ} \mathrm{C}$ for $16-20 \mathrm{~h}$. After cooling on ice, the specimen was neutralized by adding $100 \mu 1$ of $60 \%$ perchloric acid (PCA). The final PCA concentration was raised to $4 \%$ by adding an additional $150 \mu 1$ of $60 \%$ PCA, and the specimen was placed on ice for $10 \mathrm{~min}$. The specimen was then centrifuged $\left(1,200 \times \mathrm{g}, 4^{\circ} \mathrm{C}, 10 \mathrm{~min}\right)$, and the resulting supernatant was used as the RNA fraction (total volume, $2.25 \mathrm{ml}$ ). The remaining pellet was suspended and washed in $2 \mathrm{ml}$ of $4 \% \mathrm{PCA}$, and centrifuged $(1,200 \mathrm{x} \mathrm{g}$, $\left.4^{\circ} \mathrm{C}, 10 \mathrm{~min}\right)$. This pellet was then resuspended in $2 \mathrm{ml}$ of $4 \%$ PCA, heated in a boiling water bath for $15 \mathrm{~min}$, to hydrolyze DNA. After cooling, the specimen was centrifuged (1,200 x g, room temperature, $10 \mathrm{~min}$ ), and the resulting supernatant was used as the DNA fraction (total volume, $2 \mathrm{ml}$ ). A 1-ml aliquot of each sample of the RNA and DNA fraction, was removed and placed in separate vials, $10 \mathrm{ml}$ of ACS-II was added, and the radioactivity was measured.

Cell cycle phase specificity of the drug. KB cells were synchronized by a double thymidine block. Briefly, cells were incubated for $24 \mathrm{~h}$ in a medium containing $2.5 \mathrm{mM}$ thymidine, followed by incubation for $8 \mathrm{~h}$ in thymidine-free medium.
Synchronization of cells at the G1/S boundary was then achieved by further incubation for $14 \mathrm{~h}$ in $2.5 \mathrm{mM}$ thymidinecontaining medium. The thymidine block was released by washing the cells twice with PBS, followed by incubation in a fresh medium. At $0,2,4,6,8$ and $10 \mathrm{~h}$ after release from the thymidine block, TAS-106 $(2.5 \mu \mathrm{M}), 5-\mathrm{FU}(250 \mu \mathrm{M})$ and FTD $(1,000 \mu \mathrm{M})$ were applied. Following 90 -min exposure to a drug, the cells were washed with PBS, treated with trypsin/ EDTA, and suspended in culture medium. Then the cells were incubated in 96-well microplates $(n=6)$ for 3 days. The number of viable cells was determined by MTT assay. Cell cycle synchronization was assessed by flow cytometry. The cells were treated with trypsin in a spermine tetrahydrochloride detergent buffer, then trypsin inhibitor was added, followed by addition of RNase contained in a citrate-stabilizing buffer, and finally stained with $125 \mu \mathrm{g} / \mathrm{ml}$ of propidium iodide (PI) (a Cycle TEST PLUS DNA Reagent kit, Becton-Dickinson, San Jose, CA). Cell distribution according to the cell cycle phase was determined by measuring the DNA content using a FACScan flow cytometer (Becton-Dickinson).

RNA extraction. HCT-15 cells were treated with TAS-106 $(0.005,0.02,0.05,0.1 \mu \mathrm{M})$ for $72 \mathrm{~h}$ and 5 -FU $(50,500 \mu \mathrm{M})$ for $6 \mathrm{~h}$. Cells were washed in PBS and resuspended in a lysis buffer containing $0.15 \mathrm{M} \mathrm{NaCl}, 10 \mathrm{mM}$ Tris- $\mathrm{HCl}(\mathrm{pH} 7.8)$, $5 \mathrm{mM} \mathrm{MgCl}_{2}$, and $0.65 \%(\mathrm{v} / \mathrm{v})$ Nonidet (NP-40). After incubation for $10 \mathrm{~min}$, the mixture was vortexed for $10 \mathrm{sec}$ and the nuclei were pelleted by centrifugation at $500 \mathrm{x} g$ for $2 \mathrm{~min}$ at $4^{\circ} \mathrm{C}$. The cytoplasmic fraction (supernatant) was removed and the nuclei were washed in fresh lysis buffer before harvesting. The cytoplasmic fraction was centrifuged 
(A)

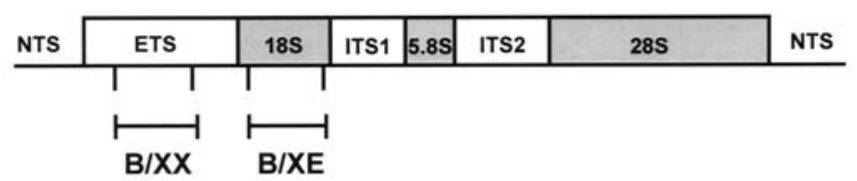

(B)

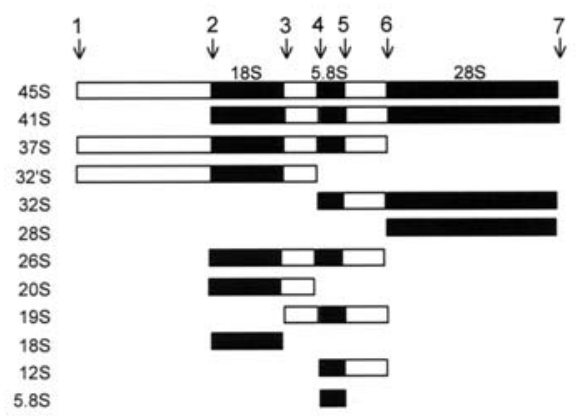

Figure 2. Human ribosomal DNA (rDNA) transcriptional unit. (A) rDNA transcriptional unit showing the origins of the rDNA probes used in this study. NTS, non-transcribed spacer; ETS, external transcribed spacer; ITS, internal transcribed spacer; $18 \mathrm{~S}, 5.8 \mathrm{~S}$ and $28 \mathrm{~S}$ mature rRNA sequences. $\mathrm{B} / \mathrm{XE}$ (Xba 1-Eco R1, $1.4 \mathrm{~kb}$ ) and B/XX (Xho 1-Xho 1, 1.4 kb) are cloned rDNA probes. (B) Possible processing sites (1-7) and the sizes of the resultant RNA molecules are indicated.

Table I. Cytotoxicity of TAS-106 and 5-FU against various tumor cell lines.

\begin{tabular}{llcr}
\hline & \multicolumn{3}{c}{$\mathrm{IC}_{50}$ values $(\mu \mathrm{M})^{\mathrm{a}}$} \\
\cline { 2 - 4 } Cell line & Origin & TAS-106 & 5-FU \\
\hline A549 & Lung & 0.0219 & 6.80 \\
HCT-15 & Colon & 0.0222 & 12.1 \\
AZ521 & Stomach & 0.0173 & 6.83 \\
VMRC-RCW & Renal & 3.11 & $>1,000$ \\
BxPC-3 & Pancreas & 0.423 & 167 \\
PC-3 & Prostate & 0.0808 & 138 \\
ME-180 & Cervix & 0.109 & 131 \\
T24 & Bladder & 0.114 & 7.71 \\
Li-4 & Liver & 0.0733 & 29.5 \\
T.T & Esophagus & 0.0798 & 30.0 \\
\hline
\end{tabular}

${ }^{a}$ The cell growth inhibition was determined by MTT assay after 72-h drug treatment.

$\left(10,000 \mathrm{x} \mathrm{g}, 10 \mathrm{~min}, 4^{\circ} \mathrm{C}\right)$ and the supernatant was used to isolate cytoplasmic RNA.

Each $3 \mathrm{ml}$ supernatant fraction was added with $3.3 \mathrm{~g}$ urea, $0.144 \mathrm{ml} \mathrm{0.5} \mathrm{M} \mathrm{EDTA,} 0.414 \mathrm{ml} 5 \mathrm{M} \mathrm{NaCl}$, and $1.44 \mathrm{ml}$ $10 \%(\mathrm{w} / \mathrm{v})$ sodium dodecyl sulphate (SDS). The solution was extracted with the mixture of phenol/chloroform/isoamyl alcohol (25:24:1). The RNA was precipitated from the aqueous layer with ethanol and resuspended in water.
Nucleic RNA was isolated by a modification of the method of Chomczynski et al (18). Nuclei were suspended in $2 \mathrm{ml}$ of denaturing solution consisting of $4 \mathrm{M}$ guanidinium thiocyanate, $25 \mathrm{mM}$ sodium citrate, $\mathrm{pH} 7.0 ; 0.5 \%$ sarcosyl and $0.1 \mathrm{M}$ 2mercaptoethanol (solution D) and homogenized by Polytron homogenizer and subsequently transferred to a polypropylene tube. The extraction solution consisting of $0.2 \mathrm{ml}$ of $2 \mathrm{M}$ sodium acetate ( $\mathrm{pH} 4.0), 2 \mathrm{ml}$ of phenol (water saturated) and $0.8 \mathrm{ml}$ of chloroform-isoamyl alchol mixture (49:1) was added to the homogenate, with thorough mixing by inversion after the addition of each reagent. The suspension was shaken vigorously for $10 \mathrm{sec}$ and cooled on ice for $15 \mathrm{~min}$. Samples were centrifuged at $10,000 \mathrm{x}$ g for $20 \mathrm{~min}$ at $4{ }^{\circ} \mathrm{C}$. After centrifugation, the aqueous phase was added with $2 \mathrm{ml}$ of isopropanol, and then placed at $-20^{\circ} \mathrm{C}$ for $1 \mathrm{~h}$ to precipitate RNA. After centrifugation at $10,000 \mathrm{x}$ g for $20 \mathrm{~min}$ at $4^{\circ} \mathrm{C}$, the RNA pellet was resuspended in $70 \%$ ethanol, sedimented, vacuum dried and dissolved in water.

Northern blot analysis of pre-rRNA processing. A sample of RNA ( $7 \mu \mathrm{g}$ per lane) was electrophoresed in a $1.1 \%$ agarose gel containing $0.66 \mathrm{M}$ formaldehyde and blotted onto a Hybond-N nylon membrane filter. The filter was hybridized with the ${ }^{32} \mathrm{P}-$ labeled rDNA probes, which are shown in Fig. 2 (19). The filter was exposed on X-ray film for $16 \mathrm{~h}$ at $-70^{\circ} \mathrm{C}$ using an intensifying screen.

\section{Results}

The main metabolic activation pathways involved in antitumor activity of TAS-106 (ECyd) and 5-FU are shown in Fig. 1.

Chemosensitivity of human cancer cells. The $\mathrm{IC}_{50}$ values of TAS-106 and 5-FU are shown in Table $\mathrm{I}$. The $\mathrm{IC}_{50}$ values varied widely from 0.0173 to $3.11 \mu \mathrm{M}$, and from 6.80 to $>1,000 \mu \mathrm{M}$, for TAS-106 and 5-FU respectively.

Intracellular metabolism of TAS-106 and 5-FU. The intracellular metabolisms of TAS-106 and 5-FU in the HT-1080 cell line are presented in Fig. 3.

TAS-106 was taken up into the cells in a time-dependent manner, and immediately converted to the nucleotides (ECMP, ECDP and ECTP). It is particularly noteworthy that the triphosphate ECTP accounted for approximately $50 \%$ of all intracellular metabolites, and showed a tendency to persist at high concentrations as the major intracellular metabolite of TAS-106. However, there was a very small amount of the TAS-106 derived metabolic species incorporated into RNA, thus accounting for approximately $3-5 \%$ of the total radioactivity taken up into the cells.

The intracellular metabolism of 5-FU, on the other hand, differed considerably from that of TAS-106. The amount of 5-FU taken up into the cells seemed to have already reached a plateau at $30 \mathrm{~min}$, and the total radioactivity incorporated into the cells was $<10 \%$ of that of TAS-106. Moreover, $>50 \%$ of the total radioactivity incorporated into the cells was present in the form of 5-FU, and metabolism of 5-FU appeared to be less intensive. Approximately $20 \%$ of the total radioactivity taken up into the cells was incorporated into RNA, one may 
(A)

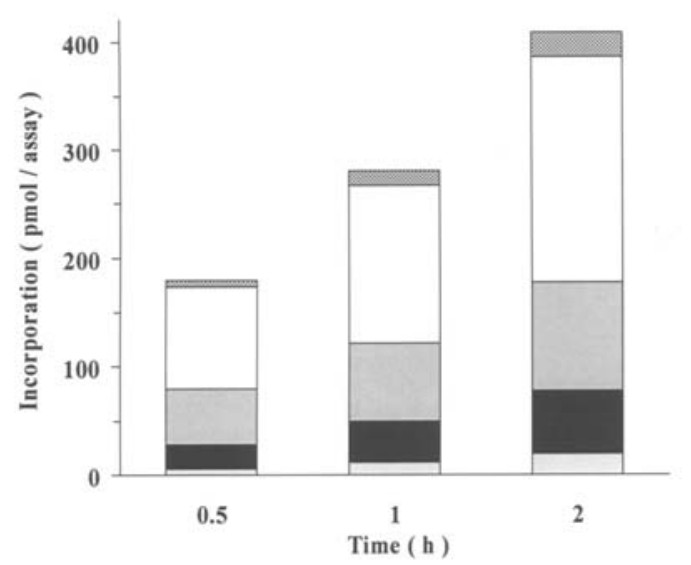

(B)

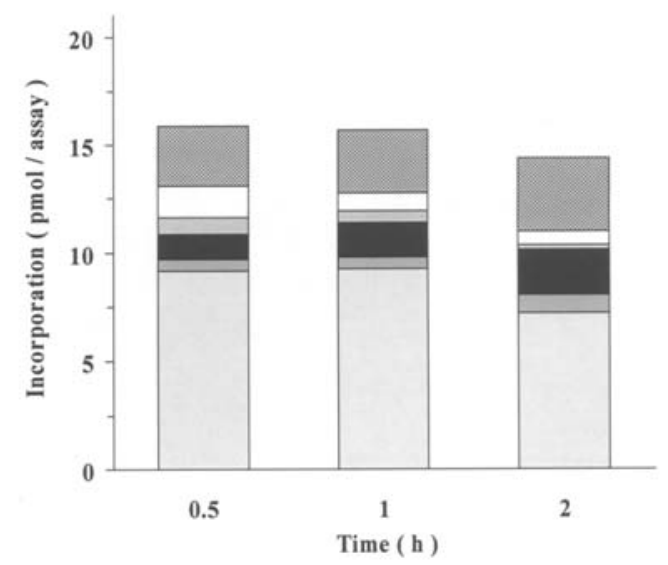

Figure 3. Intracellular metabolism of $\left[{ }^{3} \mathrm{H}\right] \mathrm{TAS}-106$ and $\left[{ }^{3} \mathrm{H}\right] 5$-FU in HT-1080 human fibrosarcoma cells. (A) $\left[{ }^{3} \mathrm{H}\right] \mathrm{TAS}-106$, dotted bars; TAS-106, closed bars; ECMP, shaded bars; ECDP, open bars; ECTP, grid bars, RNA. (B) [ $\left.{ }^{3} \mathrm{H}\right] 5-\mathrm{FU}$, dotted bars; 5-FU, striped bars; F(d)Urd, closed bars; F(d)UMP, shaded bars; F(d)UDP, open bars; F(d)UTP, grid bars, RNA.

(A)

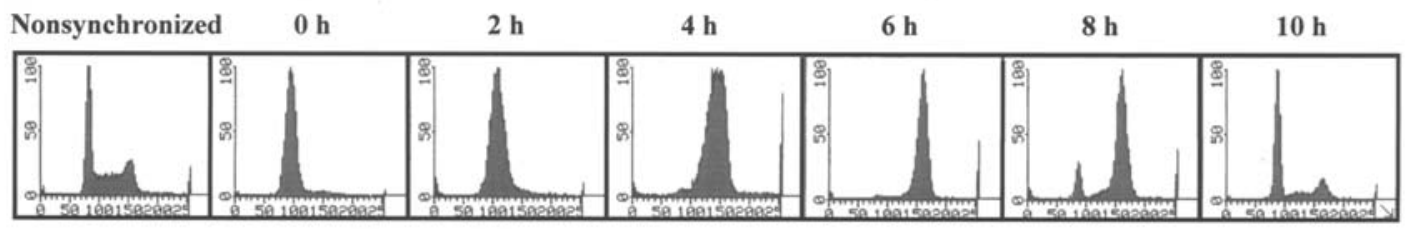

(B)

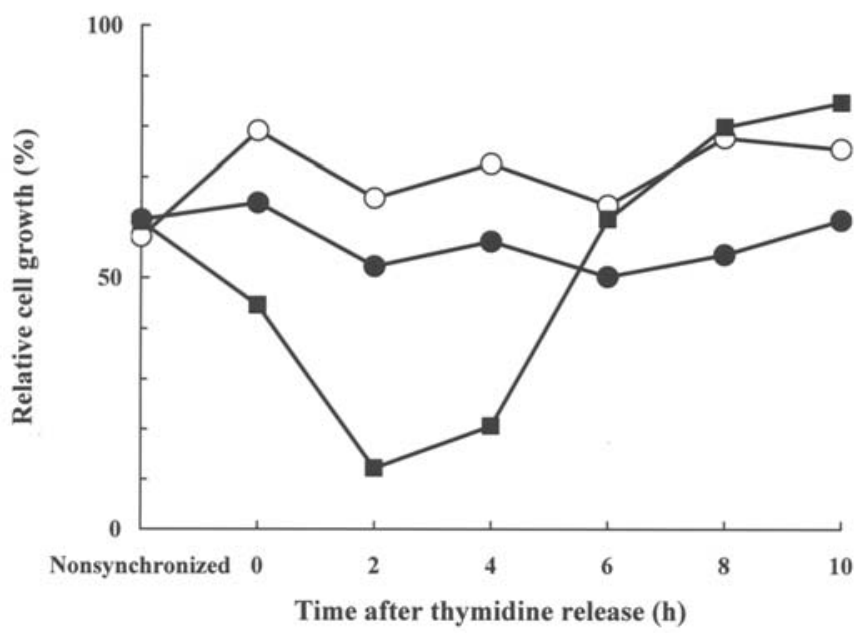

Figure 4. Cell cycle phase specificity of cytotoxic effects. KB cells were synchronized with excess thymidine. The effect of TAS-106 (•), 5-FU ( $)$ ) and FTD (匹) after thymidine release. Points on the Y-axis show the effect on non-synchronized cells.

expect that there was a rapid generation of FUTP from 5-FU via FUMP, leading to a rapid incorporation of FUTP into RNA. Any incorporation of TAS-106 and 5-FU-derived metabolic species into DNA was hardly observed.

Cell cycle phase specificity of the cytotoxic effect. The cell populations after release of the $\mathrm{S}$ phase synchronized cell from synchronization induced by the excess thymidine and their sensitivity to each of the drugs at that time are shown in Fig. 4.
Relative cell growth of the non-synchronized cells exposed to TAS-106 $(2.5 \mu \mathrm{M}), 5-\mathrm{FU}(250 \mu \mathrm{M})$, and FTD $(1,000 \mu \mathrm{M})$, the $\mathrm{S}$ phase specific antimetabolite, in relation to the control was $61.6,58.2$ and $61.1 \%$, respectively. The relative cell growth after exposure to $2.5 \mu \mathrm{M}$ TAS-106 and $250 \mu \mathrm{M}$ 5-FU in each cell cycle phase after release from $\mathrm{S}$ phase synchronization was in the range of 50.2-64.9 and 64.4-79.1\%, respectively. Since the ranges were almost the same as in the non-synchronized cells, it was concluded that the cell growth inhibitory effects of TAS-106 and 5-FU are cell 
(A)

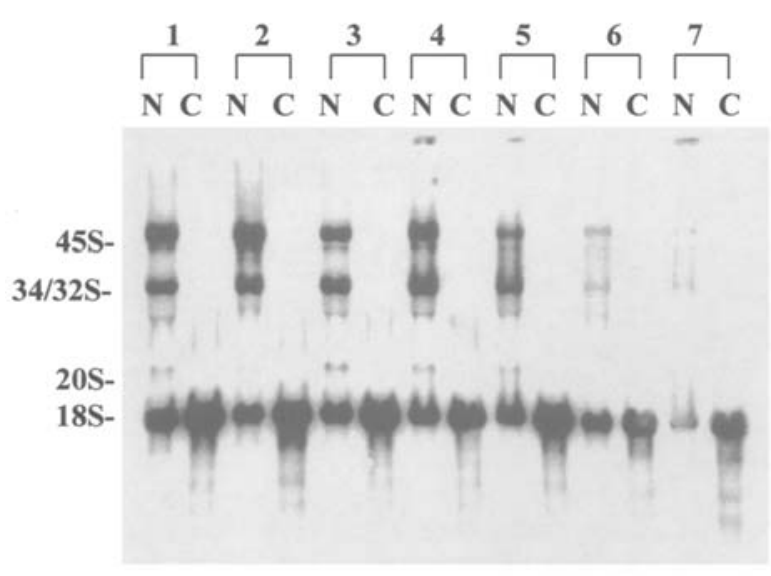

(B)
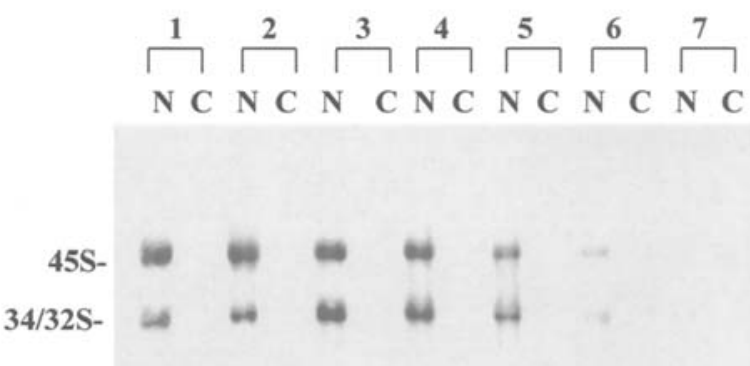

20S-

18S-

Figure 5. Effect of TAS-106 and 5-FU on pre-rRNA processing in HCT-15 human colon cancer cells. RNA from the nuclear and cytoplasmic fraction was transferred to nitrocellulose and blot-hybridised with probe $\mathrm{B} / \mathrm{XE}(\mathrm{A})$ and $\mathrm{B} / \mathrm{XX}(\mathrm{B})$. Lanes 1 and 2 , RNA from cells treated for $6 \mathrm{~h}$ with 50 and $500 \mu \mathrm{M} 5$-FU, respectively. Lane 3, RNA from untreated cells. Lanes 4-7, RNA from cells treated for $72 \mathrm{~h}$ with $0.005,0.02,0.05$ and $0.1 \mu \mathrm{M}$ TAS-106, respectively. The left lane (N) and right (C) lane correspond to the nuclear RNA and cytoplasmic RNA, respectively.

cycle-independent. This is in contrast to the effects induced by exposure to $1,000 \mu \mathrm{M}$ FTD, where the growth inhibitory effects fluctuated widely within the range of $12.2-84.7 \%$. The lowest relative cell growth occurred at $2 \mathrm{~h}$ after release from $\mathrm{S}$ phase synchronization, when the cell population consisted mainly of cells in the $S$ phase of the cell cycle, indicating that FTD shows the best growth inhibitory effect for cancer cells in the $\mathrm{S}$ phase of the cell cycle.

Pre-rRNA processing. The effects of TAS-106 and 5-FU on rRNA processing in the human colon cancer cell line HCT-15 are shown in Fig. 5.

Detection of the various classes of RNA with the rDNA probes for the $\mathrm{B} / \mathrm{XE}$ and $\mathrm{B} / \mathrm{XX}$ regions revealed a tendency for all classes of RNA to decrease in the cells exposed to $0.02 \mu \mathrm{M}$ TAS-106. Moreover, marked decreases or complete disappearance of all classes of RNA were observed in the cells exposed to TAS-106 concentrations of $0.05 \mu \mathrm{M}$ or more.

Interestingly, the concentrations of TAS-106 affecting the processing of RNA were very similar to those inducing cytotoxic effects. For instance, HCT-15 cancer cells exposed for $72 \mathrm{~h}$ to TAS-106 were sensitive to concentrations as low as $0.022 \mu \mathrm{M}\left(\mathrm{IC}_{50}\right)$ (Table I) and those concentrations were effective in the inhibition of RNA synthesis.

The ratios of 45S RNA and 34/32S RNA in the cells exposed to the 50 - or $500-\mu \mathrm{M}$ concentrations of 5-FU were compared with their ratios in the controls by using the rDNA probe for the B/XE region. As shown in Fig. 5A, the 45S RNA and 34/32S RNA were present in almost equal amounts in control cells, but there was a greater proportion of 45S RNA than 34/32S RNA in the cells exposed to 5-FU. Moreover, although very slight compared to the control, the decrease in 18S RNA and disappearance of 20S RNA were also observed in the cells treated with $500 \mu \mathrm{M}$ 5-FU.

As shown in Fig. 5B, when the rDNA probe for the $\mathrm{B} / \mathrm{XX}$ region was used as well, the 45S RNA and 34/32S RNA were found to be present in almost equal amounts in control cells, but there was more 45S RNA than 34/32S RNA in the cells treated with 5-FU.

\section{Discussion}

TAS-106, a newly developed antimetabolite drug, possesses a broad antitumor spectrum and potent antitumor activity. However, its mechanism of action was not fully elucidated, particularly, the difference between TAS-106 and 5-FU in the inhibition of RNA metabolism. Considering the effect of 5-FU on RNA, it was shown that 5-FU is incorporated into RNA to a relatively high extent. As the result, 5-FU incorporated into RNA impairs the function of RNA through the inhibition of post-transcription RNA processing $(14,20)$. The intracellular metabolism of TAS-106, however, differs greatly from that of 5-FU. The major metabolite of TAS-106 is ECTP, and the amounts of TAS-106 incorporated into RNA are only a mere $3-5 \%$ of the total radioactivity taken up into the cells. Thus, the action of TAS-106 on RNA is probably quite different from that of 5-FU.

Previous research has shown that TAS-106 strongly inhibits incorporation of $\left[{ }^{3} \mathrm{H}\right]$ guanosine into the acid-insoluble fraction (mainly RNA) of L1210 cells (3), and that ECTP inhibits the in vitro RNA transcription by human RNA polymerase II (5). Taking into account these findings, one may conclude that TAS-106 differs from 5-FU in terms of their effect on RNA synthesis. The maintenance of high intracellular concentrations of ECTP, an active metabolite of TAS-106, appears to be necessary for its cytocidal effect. Moreover, the continuous presence of the ECTP appeared to inhibit RNA synthesis, through antagonizing RNA polymerase.

It has been reported that when the cells are exposed to a short-term high concentration of 5-FU, the predominant effects are related to RNA inhibition. On the other hand, the continuous exposure to a low concentration is associated with DNA inhibition $(21,22)$. To determine the effect of 5-FU on RNA, the exposure time of 5-FU in this study was set at $6 \mathrm{~h}$ 
in accordance with a previous report (14). Since the inhibition of RNA synthesis is the principal enzyme mediated mechanism of action of TAS-106, the exposure was set at $72 \mathrm{~h}$, in the hope of obtaining sufficient effect.

rRNA is the most abundant form of cellular RNA and has a rapid rate of synthesis (14). It is, therefore, probable that a large quantity of drug would be incorporated into newly synthesized rRNA transcripts, consequently inducing an observable disruption of pre-rRNA processing. Human rRNA is composed of four species of molecules $(5 \mathrm{~S}, 5.8 \mathrm{~S}, 18 \mathrm{~S}$ and $28 \mathrm{~S}$ ), of which the last three are derived from a common $45 \mathrm{~S}$ precursor in the nucleus. There are several alternativeprocessing pathways, as deduced by Bowman et al (23).

As shown in Fig. 4, the cell cycle related drug sensitivity was well manifested in the case of FTD, whereas almost the same relative cell growth was observed in all cell cycle phases, when treated with TAS-106 and 5-FU. Based on these findings, it was concluded that FTD is an S phase specific drug, while TAS-106 and 5-FU exert their cytotoxicity in a cell cycleindependent manner.

Several other anticancer drugs exert cell cycle specific cytotoxic effects. To name a few, bleomycin is very effective in the $\mathrm{G} 2 / \mathrm{M}$ phase. $\mathrm{SN}-38$, the active metabolite of the topoisomerase I inhibitor CPT-11, is an S phase specific agent (24). Based on these reports, the sensitivity of cells to the drugs that inhibit DNA synthesis often depends on a certain phase of the cell cycle, as we also revealed in our studies on FTD.

5-FU exerted cell cycle-independent cytotoxicity that we considered to be due to a short-term exposure. The system utilized in this study, employing a synchronized cell population, could only be applied to the evaluation of cell-cycle dependency by a short-term exposure. Thus, it is possible that the brief exposure to a high concentration of 5-FU in this study reflected the RNA-synthesis-inhibitory action of FUTP and thus the sensitivity was cell cycle-independent, as in regard to TAS-106.

In addition, the differences in the mechanism of action due to 5-FU exposure schedules have also been seen in the effects on the cell cycle, as reported by the study of Inaba et al (25). When exposed to 5-FU for $72 \mathrm{~h}$, most of the cell population accumulated in the $S$ phase and remained there. When exposure to 5-FU was held at $1 \mathrm{~h}$, the cell population temporarily accumulated in the $\mathrm{S}$ phase, then the $\mathrm{G} 1$ and G2/M phase cell population subsequently increased. These findings also suggested a close connection between the mechanisms of action of 5-FU and the exposure schedule.

Since continuous intravenous infusion or continuous administration via the oral route have become the main methods of administration of 5-FU clinically, it is possible that 5-FU might display cell cycle-dependent efficacy in clinical tumors based on inhibition of DNA synthesis by a long-term exposure to low concentrations.

TAS-106, on the other hand, inhibits RNA synthesis; therefore, the sensitivity to TAS-106 is unaffected by the phases of the cell cycle. This characteristic was considered useful when used concomitantly with other drugs. Combinations with other antitumor drugs are currently being used for chemotherapy clinically. Because of the fact that antitumor drugs arrest cells in various phases, we suggest that the order and timing of their co-administration may affect their antitumor effect.

In conclusion, it is suggested that TAS-106 exerted its antitumor effect by an RNA-synthesis-inhibiting action via a mechanism different from that of 5-FU. Moreover, the above findings suggest that TAS-106 acts in a cell cycle-independent fashion, and its anticancer activity when used concomitantly with other anticancer agents may not be affected.

\section{References}

1. Matsuda A and Sasaki T: Antitumor activity of sugar-modified cytosine nucleosides. Cancer Sci 95: 105-111, 2004.

2. Hattori H, Tanaka M, Fukushima M, Sasaki T and Matsuda A: Nucleosides and nucleotides. 158. 1-(3-C-Ethynyl- $3-D-r i b o-p e n t o-$ furanosyl) cytosine, 1-(3-C-Ethynyl- $\beta-D-$ ribo-pentofuranosyl) uracil, and their nucleobase analogues as new potential multifunctional antitumor nucleosides with a broad spectrum of activity. J Med Chem 39: 5005-5011, 1996.

3. Tabata S, Tanaka M, Matsuda A, Fukushima M and Sasaki T: Antitumor effect of a novel multifunctional antitumor nucleoside, 3'-ethynylcytidine, on human cancers. Oncol Rep 3: 1029-1034, 1996.

4. Shimamoto Y, Fujioka A, Kazuno H, Murakami Y, Ohshimo H, Kato T, Matsuda A, Sasaki T and Fukushima M: Antitumor activity and pharmacokinetics of TAS-106, 1-(3-C-Ethynyl- $3-$ D-ribo-pentofuranosyl) cytosine. Jpn J Cancer Res 92: 343-351, 2001

5. Tabata S, Tanaka M, Endo Y, Obata T, Matsuda A and Sasaki T: Anti-tumor mechanisms of 3'-ethynyluridine and ethynylcytidine as RNA synthesis inhibitors: development and characterization of 3'-ethynyluridine resistant cells. Cancer Lett 116: 225-231, 1997.

6. Takatori S, Kanda H, Takenaka K, Wataya Y, Matsuda A, Fukushima M, Tanaka M and Sasaki T: Antitumor mechanisms and metabolism of the novel antitumor nucleoside analogues, 1-(3$C$-Ethynyl-B-D-ribo-pentofuranosyl) cytosine and $1-(3-C$ Ethynyl-ß-D-ribo-pentofuranosyl) uracil. Cancer Chemother Pharmacol 44: 97-104, 1999.

7. Koizumi K, Shimamoto Y, Azuma A, Wataya Y, Matsuda A, Sasaki T and Fukushima M: Cloning and expression of uridine/ cytidine kinase cDNA from human fibrosarcoma cells. Int J Mol Med 8: 273-278, 2001.

8. Hartman KY and Heidelberger C: Studies on fluorinated pyrimidines: XIII. Inhibition of thymidylate synthase. J Biol Chem 236: 3006-3013, 1961 .

9. Langenbach RJ, Danenberg PV and Heidelberger C: Thymidylate synthase: mechanism of inhibition by 5-fluoro-2'-deoxyuridylate. Biochem Biophys Res Commun 48: 1565-1571, 1972.

10. Santi DV and McHenry CS: 5-Fluoro-2'-deoxyuridylate: covalent complex with thymidylate synthase. Proc Natl Acad Sci USA 69: 1855-1857, 1972.

11. Spears CP, Shahinian AH, Moran RG, Heidelberger C and Corbett TH: In vivo kinetics of thymidylate synthase inhibition in 5-fluorouracil-sensitive and resistant murine colon adenocarcinomas. Cancer Res 42: 450-456, 1982.

12. Doong SL and Dolnick BJ: 5-Fluorouracil substitution alters pre-mRNA splicing in vitro. J Biol Chem 236: 4467-4473, 1988.

13. Glazer RI and Lloyd LS: Association of cell lethality with incorporation of 5-fluorouracil and 5-fluorouridine into nuclear RNA in human colon carcinoma cells in culture. Mol Pharmacol 21: 468-473, 1982.

14. Greenhalgh DA and Parish JH: Effect of 5-fluorouracil on cytotoxicity and RNA metabolism in human colonic carcinoma cells. Cancer Chemother Pharmacol 25: 37-44, 1989.

15. Wilkinson DS, Tlsty TD and Hanas RJ: The inhibition of ribosomal RNA synthesis and mutation in Novikoff hepatoma cells by 5-fluorouridine. Cancer Res 35: 3014-3020, 1975.

16. Mosmann T: Rapid colorimetric assay for cellular growth and survival: application to proliferation and cytotoxicity assays. J Immunol Methods 65: 55-63, 1983.

17. Schneider WC: Phosphorus compounds in animal tissues. III. Comparison of methods for the estimation of nucleic acid. J Biol Chem 164: 747-751, 1946.

18. Chomczynski P and Sacchi N: Single-step method of RNA isolation by acid guanidinium thiocyanate-phenol-chloroform extraction. Anal Biochem 162: 156-159, 1987. 
19. Maden BEH, Dent CL, Farrell T, Garde J, McCallum FS and Wakeman J: Clones of human ribosomal DNA containing the complete 18S and 28S gene. Biochem J 246: 519-527, 1987.

20. Greenhalgh DA and Parish JH: Effect of 5-fluorouracil combination therapy on RNA processing in human colonic carcinoma cells. Br J Cancer 61: 415-419, 1990.

21. Inaba M, Naoe Y and Mitsuhashi J: Flow cytometric analysis of cell-killing actions of 5-fluorouracil in human colorectal cancer cells. Oncol Res 6: 303-309, 1994.

22. Inaba M, Naoe Y, Mitsuhashi J and Ozawa S: Kinetic analysis of 5-fluorouracil action against various cancer cells. Jpn J Cancer Res 81: 1039-1044, 1990.
23. Bowman LH, Rabin B and Schlessinger D: Multiple ribosomal RNA cleavage pathway in mammalian cells. Nucleic Acids Res 9: 4951-4966, 1981

24. Aoyagi Y, Kobunai T, Utsugi T, Oh-hara T and Yamada Y: In vitro antitumor activity of TAS-103, a novel quinoline derivative that targets topoisomerase I and II. Jpn J Cancer Res 90: $578-587,1999$.

25. Inaba M and Mitsuhashi J: Flow cytometric analysis of cellkilling actions of 5-fluorouracil in human colorectal cancer cells. Oncol Res 6: 303-309, 1994. 